\title{
Penerapan Cukai Minuman Berkarbonasi, Diperlukan Kolaborasi Sektor Kesehatan dan Keuangan
}

\author{
Fajar Ramadhitya Putera \\ Kementrian Kesehatan RI, Jakarta, Indonesia \\ email: fajariyoo@yahoo.com
}

\section{Abstrak :}

Keamanan makanan merupakan isu yang terkait dengan berbagai bidang seperti kesehatan, perdagangan dan perindustrian sehingga penanganannya pun dapat dilakukan melalui pendekatan lintas sektor. Saat ini pemerintah sedang membahas rencana penerapan cukai pada minuman ringan berkarbonasi. Sesuai UU No. 39 Tahun 2007 tentang Perubahan atas UU No. 11 Tahun 1995 tentang cukai. Penetapan Barang Kena Cukai untuk minuman ringan berkarbonasi yang berpemanis atas dasar dampak kesehatan dikaji dengan mempertimbangkan data-data pendukung keterkaitan pola konsumsi minuman tersebut di Indonesia dan dampak kesehatannya melalui Studi Diet Total (SDT). Perspektif kesehatan masyarakat cenderung mendorong penetapan pajak yang cukup tinggi untuk memicu efek yang bermakna pada pola konsumsi. Dalam prakteknya, sebagian besar pajak ditetapkan sekitar 10\%, meskipun Saudi Arabia dan Uni Emirat Arab baru baru ini menerapkan pajak hingga 100\% untuk minuman berpemanis. Bentuk paling efektif sepertinya cukai yang diterapkan pada basis volume atau berat dan dimasukkan ke dalam harga jual. Pajak dalam persentase harga cenderung mendorong konsumen untuk melakukan substitusi ke produk yang lebih murah namun bukan produk yang lebih sehat. Efektivitas intervensi fiskal dapat ditingkatkan dengan upaya edukasi konsumen terkait dasar pengenaan pajak pada produk. Di Meksiko, penerapan pajak pada minuman berpemanis disertai dengan kampanye pemberdayaan masyarakat yang dirancang untuk mendukung perubahan perilaku dan intervensi struktural untuk meningkatkan ketersediaan air yang dapat diminum.

Keyword : cukai, minuman berkarbonasi, fiskal

\section{Outline}

- Pendahuluan

- Data dan fakta minuman berkarbonasi

- Kebijakan cukai minuman berkarbonasi di dunia internasional

- Prespektif paling efektif dalam penerapan cukai minuman berkarbonasi

- Kesimpulan

\section{Pendahuluan}

Saat ini pemerintah sedang membahas rencana penerapan cukai pada minuman ringan berkarbonasi. Sesuai UU No. 39 Tahun 2007 tentang Perubahan atas UU No. 11 Tahun 1995 tentang cukai.

cukai adalah pungutan negara yang dikenakan terhadap barang-barang tertentu yang mempunvai sifat atau karakteristik vana konsumsinva perlu dikendalikan, peredarannva 
Pada tahun 2014 Kementerian Kesehatan menyelenggarakan SDT sebagai upaya mewujudkan tersedianya data kecukupan dan keamanan makanan yang dikonsumsi oleh penduduk Indonesia. SDT terdiri dari dua kegiatan besar yaitu kegiatan Survei Konsumsi Makanan Individu (SKMI) dan Analisis Cemaran Kimia Makanan (ACKM). SKMI berperan untuk memperoleh data kecukupan makanan yang dikonsumsi, dan ACKM untuk mengetahui data keamanan makanan yang dikonsumsi.

Penelitian ini memberikan informasi rata-rata makanan yang dikonsumsi individu menurut jenis dan kelompok makanan, tingkat asupan zat gizi (makro dan mikronutrien) individu, serta identifikasi kekurangan dan kelebihan konsumsi zat gizi individu. Data ini menjadi dasar kebijakan pemerintah dalam rangka menguatkan program pangan, gizi dan kesehatan masyarakat.

\section{Data dan fakta minuman berkarbonasi}

Menurut data Asosiasi Industri Minuman Ringan (ASRIM) konsumsi minuman ringan berkarbonasi di Indonesia pada tahun 2011 hanya 2,4 liter per kapita sedangkan di Australia pada tahun 1998-1999 sebanyak 113 liter per kapita. Jika minuman ringan berkarbonasi pada umumnya dikemas dalam botol $250 \mathrm{~mL}$, dapat disimpulkan bahwa konsumsi minuman ringan berkarbonasi tidak lebih dari 10 (sepuluh) botol per kapita per tahun. Sementara data konsumsi di Filipina mencapai 34,1 liter, Malaysia 19 liter, Vietnam 6,2 liter dan Kamboja 4,5 liter.

Kandungan komponen kafein, gula dan pemanis buatan di dalam minuman ringan berkarbonasi yang berpemanis di Indonesia pada umumnya masih dalam rentang aman, namun apabila dikonsumsi berlebihan tentu dapat berdampak pada kesehatan. Perjanjian World Trade Organization mensyaratkan bahwa keputusan terkait perdagangan internasional didasarkan pada penilaian risiko secara ilmiah. Batas toleransi keamanan bahan kimia bergantung pada asupan total semua sumber paparan yang perlu dipertimbangkan dalam melakukan penilaian risiko.

\section{Kebijakan cukai minuman berkarbonasi di dunia internasional}

Pada tahun 2016, World Health Organization (WHO) merekomendasikan "implementasi pajak pada minuman berpemanis" sebagai salah satu upaya kunci menangani masalah kesehatan seperti obesitas pada anak-anak. Intervensi fiskal dapat membantu penanganan masalah kesehatan ketika harga suatu produk tidak sepenuhnya mencerminkan biaya sosialnya.

Kebijakan serupa telah diterapkan di 29 yurisdiksi. Pajak untuk minuman berpemanis gula diterapkan secara nasional antara lain di Brunei Darussalam, Meksiko, Chili, Finlandia, Prancis, Spanyol, Arab Saudi dan secara lokal di beberapa negara bagian di Amerika Serikat. Pajak untuk makanan kaya gula, garam dan lemak diterapkan di Hungaria dan Tonga. Di Fiji dan Tonga, subsidi implisit dilakukan melalui pencabutan tarif impor untuk buah dan sayur. Namun di beberapa negara, kebijakan ini menghadapi sejumlah tantangan. Di Denmark, sebagai contoh, pajak untuk lemak jenuh dicabut setelah satu tahun penerapannya.

Pengambil keputusan dari sektor kesehatan dan keuangan perlu berkolaborasi dalam merancang kebijakan ini. Sektor kesehatan lebih berfokus pada upaya meningkatkan kesehatan masyarakat melalui perubahan diet. Sektor keuangan boleh jadi memiliki 
Pengambil kebijakan perlu memperhatikan regresifitas yakni apakah pajak akan jatuh pada masyarakat berpenghasilan rendah secara tidak proporsional. Tiga aspek kunci yang perlu dipertimbangkan. Pertama, menurut bukti epidemiologi yang tersedia, makanan apa yang terkait dengan dampak kesehatan. Kedua, sejauh mana konsumsi makanan tersebut memberi dampak negatif bagi masyarakat. Ketiga, target mana yang paling memungkinkan secara perspektif administratif.

\section{Prespektif paling efektif dalam penerapan cukai minuman berkarbonasi}

Estimasi menunjukkan bahwa minuman tersebut memiliki rerata elastisitas harga sekitar -1 , artinya bahwa peningkatan $1 \%$ pada harga ritel mendorong penurunan konsumsi sekitar $1 \%$. Studi meta-analisis menunjukkan bahwa tiap peningkatan $10 \%$ pada harga ritel terjadi penurunan konsumsi mulai dari 3\% hingga 9\%. Pajak sebesar $10 \%$ pada minuman berpemanis gula di Meksiko dan Chili, diperkirakan mengurangi konsumsi nasional sebanyak $7 \%$.

Subsidi untuk buah dan sayuran terbukti efektif dalam meningkatkan konsumsi. Di Afrika Selatan, subsidi $10 \%$ dan $25 \%$ pada buah dan sayuran mendorong peningkatan asupan harian buah dan sayur sebanyak 0,38 dan 0,64 tiap sajian per orang.

Perspektif kesehatan masyarakat cenderung mendorong penetapan pajak yang cukup tinggi untuk memicu efek yang bermakna pada pola konsumsi. Dalam prakteknya, sebagian besar pajak ditetapkan sekitar 10\%, meskipun Saudi Arabia dan Uni Emirat Arab baru baru ini menerapkan pajak hingga 100\% untuk minuman berpemanis.

Bentuk paling efektif sepertinya cukai yang diterapkan pada basis volume atau berat dan dimasukkan ke dalam harga jual. Pajak dalam persentase harga cenderung mendorong konsumen untuk melakukan substitusi ke produk yang lebih murah namun bukan produk yang lebih sehat.

Efektivitas intervensi fiskal dapat ditingkatkan dengan upaya edukasi konsumen terkait dasar pengenaan pajak pada produk. Di Meksiko, penerapan pajak pada minuman berpemanis disertai dengan kampanye pemberdayaan masyarakat yang dirancang untuk mendukung perubahan perilaku dan intervensi struktural untuk meningkatkan ketersediaan air yang dapat diminum.

\section{Daftar Pustaka}

https://www.who.int/bulletin/volumes/96/3/17-195982/en/

Bulletin of the World Health Organization 2018;96:201-210. doi: http://dx.doi.org/10.2471/BLT.17.195982

http://www.litbang.depkes.go.id.

UU No. 39 Tahun 2007 tentang Perubahan atas UU No. 11 Tahun 1995 tentang Cukai. 